\title{
16S rDNA Typing of Salmonella Typhi Strains from Different Geographical Locations in Sumba Island East, Nusa Tenggara, Indonesia
}

\author{
CHARIS AMARANTINI* AND TRI YAHYA BUDIARSO \\ Biology Department, Universitas Kristen Duta Wacana, Jalan dr Wahidin Sudirohusodo 5-19, \\ Yogyakarta 55224, Indonesia
}

\begin{abstract}
A total of thirteen isolates representative of Salmonella Typhi from different geographical locations in Sumba Island, East Nusa Tenggara, Indonesia were identified by 16S rDNA gene sequences. Bacterial DNA extraction was prepared by using a Purelink ${ }^{\mathrm{TM}}$ Genomic DNA kit. The bacterial DNA and control were amplified using the specific primers for $S$. Typhi. These $16 \mathrm{~S}$ rDNA gene sequence data were aligned with the corresponding available $S$. Typhi sequence and the reference organisms from the family Enterobacteriaceae from NCBI database by using the CLUSTAL X software. Phylogenetic trees were generated using the PHYLIP software package and the matrix of nucleotide similarity and nucleotide difference were generated by using the PHYDIT software. The results from the $16 \mathrm{~S}$ rDNA analysis showed that the degree of similarity within these strains ranged from $99.13-100 \%$. The percentage of sequence similarity between $S$. Typhi strains was very high $(>99 \%)$. Molecular phylogenetic analysis showed that all of the isolates formed a new center of diversity with $S$. Typhi ATCC $19430^{\mathrm{T}}$ as a reference strain. Based on these results, all of the tested strains belonged to species of $S$. Typhi suggested by their relatedness with the type strain of $S$. Typhi ATCC $19430^{\mathrm{T}}$.
\end{abstract}

Key words: 16S rDNA, phylogenetic analysis, Salmonella Typhi, typing

Sebanyak 13 isolat Salmonella Typhi yang mewakili berbagai wilayah geografis di pulau Sumba, Nusa Tenggara Timur, Indonesia diidentifikasi berdasarkan sekuen gen 16S rDNA. DNA bakteri diekstraksi sesuai dengan petunjuk dari Purelink ${ }^{\mathrm{TM}}$ Genomic DNA kit. DNA bakteri dan kontrol diamplifikasi menggunakan primer spesifik untuk $S$. Typhi. Urutan basa sekuen gen $16 \mathrm{~S}$ rDNA dianalisis bersama dengan sekuen $16 \mathrm{~S}$ rDNA $S$. Typhi dan anggota famili Enterobacteriaceae yang diperoleh dari database NCBI menggunakan program ClustalX. Pohon filogeni dikonstruksi dengan menggunakan program PHYLIP sedangkan matriks similaritas dan perbedaan nukleotida dianalisis dengan menggunakan program PHYDIT. Hasil analisis sekuen 16S rDNA menunjukkan bahwa kemiripan di antara isolat $S$. Typhi berkisar antara 99,13-100\%. Persentase kemiripan sekuen di antara isolat $S$. Typhi sangat tinggi (>99\%). Analisis filogeni menunjukkan bahwa semua isolat membentuk pusat keanekaragaman baru dengan isolat standard $S$. Typhi ATCC $19430^{\mathrm{T}}$. Berdasarkan hasil tersebut, dapat disimpulkan bahwa semua isolat yang diuji tergolong dalam spesies $S$. Typhi yang ditunjukkan dari kedekatan hubungan kekerabatan dengan isolat standard $S$. Typhi ATCC $19430^{\mathrm{T}}$.

Kata kunci: 16S rDNA, analisis filogenetik, Salmonella Typhi, typing

Molecular techniques have become increasingly popular and potentially useful tool for the classification and identification of bacterial strains in most bacterial genera. One of which is $16 \mathrm{~S}$ rDNA gene sequence analysis. The $16 \mathrm{~S}$ rDNA gene is highly conserved within a species and among species of the same genus, and therefore it can be used as a reference for the speciation of bacteria (Woo et al. 2000). This method plays an important role in the identification of bacterial pathogens, which is useful not only for diagnosis, but also for phylogenetic classification. Most Salmonella strains are identified serologically as having $\mathrm{O}$ (somatic) and $\mathrm{H}$ (flagellar) antigens. There are, however, often serological cross-reaction between strains that phylogenetic classification is important to distinguish them from one another (Woo et al.2001).

*Corresponding author; Phone: +62-274-563929, Fax: +62274-513235,E-mail: charis@ukdw.ac.id
Currently there are three known species in the Salmonella genus, Salmonella enterica, Salmonella bongori, and Salmonella subterranea (Shelobolina et al. 2004). Salmonella enterica comprises of six subspecies. They are $S$. enterica subsp. enterica (subsp. I), S. enterica subsp. salamae (subsp. II), S. enterica subsp. arizonae (IIIa subsp.), S. enterica subsp. diarizonae (subsp. IIIa), S. enterica subsp. houtenae (subsp. IV), and S. enterica subsp. indica (subsp. VI). Salmonella bongori was originally classified as $S$. enterica subspecies V. The majority of $S$. enterica subsp. enterica (subsp. I) cause most infections in humans and warm-blooded animals (Truper 2005; Tajbakhsh et al.2011).

Salmonella Typhi, the agent of typhoid fever, is included in subspecies I: $S$. enterica subsp. enterica serotype Typhi (S. enterica serovar Typhi; Salmonella 
Typhi). Typhoid fever is most prevalent in tropical areas, including Indonesia (Moehario 2009). In Sumba Island, East Nusa Tenggara especially in Soutwest Sumba District over 197 cases or 725 infection/100.000 inhabitants were recorded in the database of the Karitas Hospital in 2006 (Amarantini et al. 2009). This number was higher than the average infection cases in rural areas in Indonesia, and it was nearly the same as the average cases in urban areas (810/100.000) according to World Health Organization (WHO) in 2003. These numbers suggested that the area was a good niche for fast growing microorganisms. Analysis of various $S$. Typhi strains using numerical systematic method showed that there were a big diversities in the use of the carbon sources by the $S$. Typhi isolates in these region (Amarantini et al. 2009). In addition to obtaining accurate data and strong discriminative ability to distinguish the strains, this study was aimed to identify and unravel the diversities of $S$. Typhi isolates from typhoid fever patients using molecular phylogenetic approach based on 16S rDNA gene sequences.

\section{MATERIALS AND METHODS}

Bacterial Strains. Thirteen isolates used in this research were isolated from the blood cultures of typhoid patients in Sumba Island. They came from different geographical regions in Karitas Hospital in Weetabula, a private clinic in Elopada Subdistrict in Southwest Sumba District, and Lendemoripa Hospital in Waikabubak in West Sumba District. Specimen collection methods were described in the journal article published previously (Amarantini et al. 2009). These isolates were identified using microbiological standard methods. All cultures were screened in Chromocult Coliform Agar (CCA). Typical colonies appear white and transparents due to the lack of $\beta$ - galactosidase and ß-glucoronidase enzymes. These colonies were confirmed using Triple Sugar Iron Agar (TSIA) (WHO 2003). All cultures were grown at $30{ }^{\circ} \mathrm{C}$ for $24 \mathrm{~h}$ on Brain Heart Infusion (BHI) agar before used.

Extraction of Bacterial DNA, PCR Amplification, and DNA Sequencing. Bacterial DNA was extracted in accordance with the protocol's instructions using a Purelink ${ }^{\mathrm{TM}}$ Genomic DNA Mini Kit (Invitrogen K1820-00). The bacterial DNA and control were amplified with $25 \mathrm{pmol}$ primers $\left(1^{\mathrm{st}} \mathrm{Base}\right.$ Custom Oligos FBCO) and PCR SuperMix (illustra ${ }^{\mathrm{TM}}$ PuRe $T a q^{\mathrm{TM}}$ Ready-To-Go ${ }^{\text {TM }}$ PCR beads. PCR amplification for the 16S rDNA sequences showed bands of $428 \mathrm{bp}, 484 \mathrm{bp}$, and $483 \mathrm{bp}$. These fragments were amplified using primer R1 FR, R3 FR, and R5 FR respectively. The primers used to amplify these fragments are shown in Table 1 (Massi et al. 2005). The PCR mixtures were amplified for 40 cycles at $94^{\circ} \mathrm{C}$ for 1 minute, $55^{\circ} \mathrm{C}$ for 1 min, and $72{ }^{\circ} \mathrm{C}$ for $2 \mathrm{~min}$, with a final extension at $72^{\circ} \mathrm{C}$ for 10 min in automated Applied Biosystems GeneAmp PCR System 2400. An aliquot of $5 \mu \mathrm{L}$ of each amplified product was electrophoresed in 3.0\% (w/v) agarose gel, with a 100 bp DNA Ladder (Gene Ruler $\left.{ }^{\mathrm{TM}}\right)$.

The PCR product was gel purified with a QIAquick PCR purification kit (QIAgen, Hilden, Germany). The purified PCR product was sequenced with ABI Prism 3100-Avant Genetic Analyzer according to the manufacturer's instructions (Applied Biosystems, USA) using the same primers as used in PCR.

The PCR product was gel purified with a QIAquick PCR purification kit (QIAgen, Hilden, Germany). The purified PCR product was sequenced with ABI Prism 3100-Avant Genetic Analyzer in accordance with the manufacture's instructions (Applied Biosystems, USA) using PCR primers.

Analysis and Alignment of 16S rDNA Nucleotide Sequences. The 16S rDNA nucleotide sequences were analyzed, edited and assembled with Finch TV 1.4.0 and DNA Baser sequence analysis software. Complete assembled sequences were aligned with the corresponding $S$. Typhi sequences retrieved from the NCBI database with CUSTAL X software (Thompson etal. 1997).

Construction of Phylogenetic Tree. Based on 16S rDNA nucleotide sequences, a phylogenetic tree was constructed with PHYLIP software package (Felsenstein 1993) with neighbor-joining algorithm (Saito and Nei 1987). The evolutionary distance matrix of the neighbor-joining method was generated according to the description from Jukes and Cantor (1969). The phylogenetic distances were obtained by adding only the values of the horizontal components. Eventually, the matrix of the nucleotide similarity and difference was generated with PHYDIT software (Chun 1999).

\section{RESULTS}

Thirteen isolates used in this research came from different locations; seven isolates from East Wewewa, three isolates from Kodi, two isolates from North Wewewa, and one isolate from Waikabubak. These isolates were selected to represent their geographical origins. They're mapped according to the infected patient's place of residence based on global positioning system (Fig 1). 
Phylogenetic analysis results of $13 S$. Typhi isolates based on 16S rDNA gene sequences are shown in Fig 2. The 16s rDNA gene sequences of these isolates were initially compared to those of the Enterobacteriaceae family reported in the Gene Bank with the accesion
Omba Rade), HB 10 (isolated from Weedindi), HB11 (isolated from Durru Lodo), HB12 (isolated from Kongge), and HB13 (isolated from Elopada).

The second clade consisted of five strains, which were HB02 (isolated from Kampung Sawah Waikabubak),

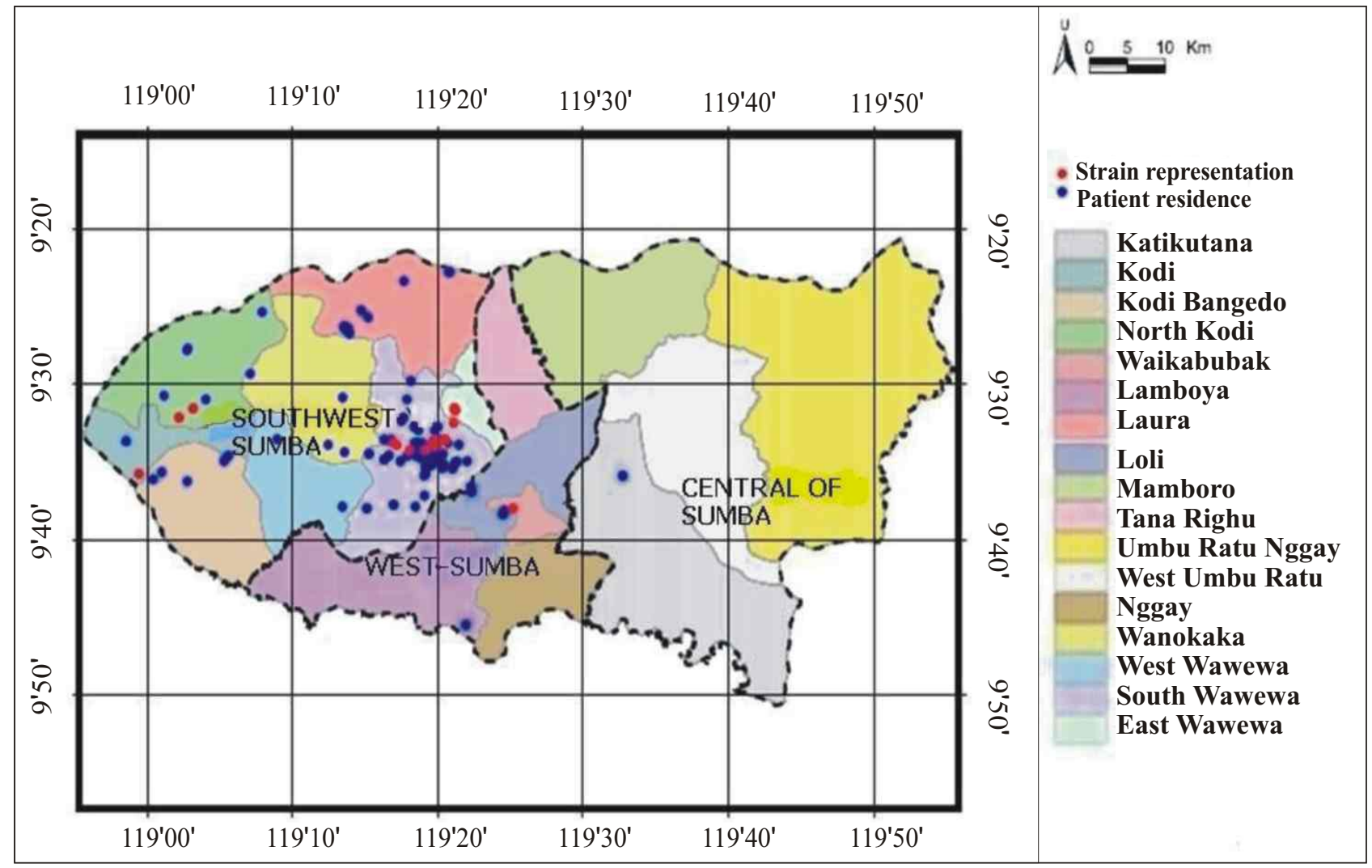

Fig 1 Distribution of typhoid fever patients and 13 strains representation from different geograophic location in Sumba Island, East Nusa Tenggara.

number Z47544 (S. Typhi ATCC 19430'), AF029227 (S. bongori BR 1859), X80724.1 (Escherichia coli ATCC 25922), M59291 (Citrobacter freundii ATCC29935), M59160 (Serratia marcescens), M59149 (Erwinia carotovora ATCC 15713), X75275 (Yersinia ruckeri ATCC 29473), X75279 (Yersinia intermedia ER-3854), M59155 (Hafnia alvei ATCC 13337), X82248 (Photobacter luminescens DSM 3368), X82251 (Xenorhabdus nematophilus DSM 3370), X07652 (Proteus vulgaris IFAM 1731), and M59159 (Plesiomonas shigelloides)

The phylogenetic analysis showed 13 representative strains of $S$. Typhi originated from different locations in Sumba Island, East Nusa Tenggara, which were then divided into three clades. The first clade consisted of seven strains. One isolate (HB01) originated from Wailabubu, North Kodi Subdistrict and six isolates were obtained from East Wewewa Subdistrict, which were HB05 (isolated from Wanowitu), HB09 (isolated from
HB07 (isolated from Weerambo, East Wewewa), HB06 (isolated from Ombawawi North Wewewa), HB03 (isolated from Watubero Wailabubur North Kodi), and HB04 (isolated from Pakamutu, Bondokodi Kodi).

The third clade consisted of two strains. They were HB08 (isolated from Palekki/Mahaloko in North Wewewa Subdistrict) and S. Typhi ATCC 19430', which was the reference strain.

The 16S rDNA nucleotide similarity values (\%) and the number of nucleotide differences among $13 \mathrm{~S}$. Typhi isolates from infected patients in different geographical locations in Sumba Island and the reference strain $S$. Typhi ATCC $19430^{\mathrm{T}}$ are shown in Table 1 and 2. The sequences of the 13 strains and $S$. Typhi ATCC $19430^{\mathrm{T}}$ showed $>99 \%$ similarity. It was also evident that strain HB10 was identical with the strain HB09, and the strain HB11 was identical with the strains HB09 and HB10 (Table 2). The two other strains (HB03 and HB04) were also identicals (Table 3). 
Table 1 The primers used for PCR amplification of 16S rDNA gene sequence of Salmonella Typhi

\begin{tabular}{lll}
\hline Primer & Sequence & Nucleotide position \\
\hline R1F & 5' AGTTTGATCCTGGCTCAG 3'* & 3-20 (AC: Z47544) \\
R1R & 5' AGTACTTTACAACCCGAAGG 3'* & 411-430 (AC: Z47544) \\
R3F & 5' AAGTACTTTCAGCGGGGA 3'* & 424-441 (AC: Z47544) \\
R3R & 5' TTGAGTTTTAACCTTGCGG 3'* & 898-916 (AC: Z47544) \\
R5F & 5' AACTCAAATGAATTGACGG 3'* & 901-919 (AC: Z47544) \\
R5R & 5' AGGCCCGGGAACGTATTCAC 3'* & 1364-1383 (AC: Z47544) \\
\hline
\end{tabular}

AC: GenBank accession no. *Reference: Massi et al. 2005

Table 2 16S rDNA similarity values (\%) and the number of nucleotide differences between seven strains and the reference strains of S.Typhi ATCC $19430^{\mathrm{T}}$ within the first clade

\begin{tabular}{|c|c|c|c|c|c|c|c|c|c|}
\hline & HB09 & HB10 & HB11 & HB12 & HB01 & HB13 & HB05 & $\begin{array}{l}\text { S. Typhi } \\
\text { ATCC } \\
19430^{\mathrm{T}}\end{array}$ & $\begin{array}{l}\text { S. bongori } \\
\text { BR1859 }\end{array}$ \\
\hline HB09 & --- & $0 / 1383$ & $0 / 1381$ & $7 / 1382$ & 4/1383 & $1 / 1382$ & $1 / 1381$ & $5 / 1381$ & $33 / 1377$ \\
\hline HB10 & 100.00 & --- & $0 / 1381$ & $7 / 1381$ & 3/1382 & $1 / 1382$ & $1 / 1381$ & $5 / 1381$ & $33 / 1377$ \\
\hline HB11 & 100.00 & 100.00 & --- & $7 / 1381$ & $3 / 1381$ & $1 / 1381$ & $1 / 1381$ & $5 / 1381$ & $33 / 1377$ \\
\hline HB12 & 99.49 & 99.49 & 99.49 & --- & $11 / 1382$ & $8 / 1381$ & $8 / 1381$ & $12 / 1381$ & $40 / 1377$ \\
\hline HB01 & 99.71 & 99.78 & 99.78 & 99.20 & --- & $4 / 1382$ & $4 / 1381$ & $8 / 1381$ & $36 / 1377$ \\
\hline HB13 & 99.93 & 99.93 & 99.93 & 99.42 & 99.71 & & $2 / 1381$ & $6 / 1381$ & $34 / 1377$ \\
\hline HB05 & 99.93 & 99.93 & 99.93 & 99.42 & 99.71 & 99.86 & --- & 4/1381 & $32 / 1377$ \\
\hline $\begin{array}{c}S . \text { Typhi } \\
\text { ATCC } \\
19430^{\mathrm{T}}\end{array}$ & 99.64 & 99.64 & 99.64 & 99.13 & 99.42 & 99.57 & 99.71 & --- & $36 / 1497$ \\
\hline $\begin{array}{c}\text { S. bongori } \\
\text { BR1859 }\end{array}$ & 97.60 & 97.60 & 97.60 & 97.10 & 97.39 & 97.53 & 97.68 & 97.60 & --- \\
\hline
\end{tabular}

Table 3 16S rRNA similarity values (\%) and the number of nucleotide differences between six strains and the reference strains of $S$. Typhi ATCC $19430^{\mathrm{T}}$ within the two and the third clades

\begin{tabular}{|c|c|c|c|c|c|c|c|c|}
\hline & HB03 & HB04 & HB06 & HB02 & HB07 & НB08 & $\begin{array}{c}\text { S. Typhi } \\
\text { ATCC } \\
19430^{\mathrm{T}}\end{array}$ & $\begin{array}{c}\text { S. bongori } \\
\text { BR1859 }\end{array}$ \\
\hline HB03 & --- & $0 / 1384$ & $5 / 1381$ & $5 / 1381$ & $6 / 1381$ & 4/1381 & 7/1381 & $35 / 1377$ \\
\hline HB04 & 100.00 & --- & $5 / 1381$ & $5 / 1381$ & $6 / 1381$ & $4 / 1381$ & 7/1381 & $35 / 1377$ \\
\hline HB06 & 99.64 & 99.64 & --- & $4 / 1381$ & $5 / 1381$ & $3 / 1381$ & $6 / 1381$ & $34 / 1377$ \\
\hline HB02 & 99.64 & 99.64 & 99.71 & --- & $1 / 1382$ & $3 / 1381$ & $6 / 1381$ & $34 / 1377$ \\
\hline HB07 & 99.57 & 99.57 & 99.64 & 99.93 & --- & $4 / 1381$ & 7/1381 & $35 / 1377$ \\
\hline HB08 & 99.71 & 99.71 & 99.78 & 99.78 & 99.71 & --- & $3 / 1381$ & $33 / 1377$ \\
\hline $\begin{array}{c}\text { S. Typhi } \\
\text { ATCC } \\
19430^{\mathrm{T}}\end{array}$ & 99.49 & 99.49 & 99.57 & 99.57 & 99.49 & 99.78 & --- & $36 / 1497$ \\
\hline $\begin{array}{c}\text { S. bongori } \\
\text { BR1859 }\end{array}$ & 97.46 & 97.46 & 97.53 & 97.53 & 97.46 & 97.60 & 97.60 & --- \\
\hline
\end{tabular}






Fig 2 Neighbour-joining phylogeny tree constructed on the basis of 16S rDNA gene sequences showing relationship amongst the thirteen representatives of $S$. Typhi isolates from the different locations in Sumba Island, East Nusa Tenggara. The arrow indicates estimated root position of the three as determined using Plesiomonas shigelloides (M59159) as an outgroup. Bar, 1 substitution per 100 nucleotides.

\section{DISCUSSION}

Phylogenetic analysis based on comparison of $16 \mathrm{~S}$ rDNA nucleotide sequences of the 13 strains with the corresponding nucleotide sequence of available representatives of the genus Salmonella clearly showed that all of the tested strains form a new center of diversity with $S$. Typhi ATCC $19430^{\mathrm{T}}$ (Fig 2). This result directly proved that all of the isolates belong to $S$. Typhi species because of their relationships with the reference strain $S$. Typhi ATCC $19430^{\mathrm{T}}$. It was also shown that strains within the species have diverse $16 \mathrm{~S}$ rDNA gene sequences. In fact, all of the strains fall into three clades. These clades demostrated that genetic diversity of the tested strains could be unraveled using phylogenetic tree based on 16S rDNA sequences.

It is shown in phylogenetic tree that each clade is made up of strains from different geographical areas in the Sumba Island especially in Southwest Sumba District. The six tested strains within the first clade 
were derived from East Wewewa Subdistrict, whereas the other isolates were derived from North Kodi Subdistrict. The second clade consisted of two strains originally from Kodi, one strain derived from Waikabubak, and the two strains derived from East Wewewa and North Wewewa. Based on the coordinate position of the infected patient's residences (Fig 1), we learned how the typhoid fever spreads among the inhabitants. Most of the patients lived in East Wewewa Subdistrict. It appears that the strains were distributed in finger pattern to nearby subdistrict such as North Wewewa, South Wewewa, West Wewewa, and then goes further out to the Kodi Bangedo, Kodi, and North Kodi. Therefore, these results indirectly showed that there were inter geographical distribution of the strains due to migration of people in this area.

Identification to the species level requires that the tested strains 16S rDNA sequence has 99\% similarity with the sequence of the reference strain in GenBank (Drancourt et al. 2000). It is shown in this study that the 16S rDNA sequence of these 13 isolates had $>99 \%$ similarity with the sequence of the closest strain in GenBank. Thus these isolates were identified as $S$. Typhi.

In terms of nucleotide similarity and nucleotide differences (Table 1), it was shown that the strain HB10 was identical with HB09, and the strain HB11 was identical with HB09 and HB10. However, this result did not entirely coherent with its phylogenetic relatedness based on phylogenetic tree. It is apparent in Fig 2 that the closest strain was found to be the strain HB12. Two tested strains, HB03, and HB 04 (Table 2), were fully congruent in their similarity values, nucleotide differences and phylogenetic analysis. It is especially interesting that the strain HB 08 from Palekki/Mahaloko North Wewewa was found to be closely related to $S$. Typhi ATCC $19430^{\mathrm{T}}$.

Based on analysis of housekeeping and rRNA genes, it has been understood that the genus Salmonella contains two lineages that had diverged considerably from each other during evolution. These lineages represent two distinct species, $S$. enterica and $S$. bongori (Baumler et al. 1998). Christensen et al. (1998) also demostrated that the analysis of 16S rDNA sequences separated $S$. bongori from $S$. enterica, and these two species from the complex of E. coli and Shigella species. This corresponds to the topology of this phylogeny tree (Fig 2).

In summary, all the isolates were identified as $S$. Typhi species because of their association with the type strain of $S$. Typhi ATCC $19430^{\mathrm{T}}$. The fact that the 13 isolates belonging to $S$. Typhi species formed a new center of diversity within the $16 \mathrm{~S}$ rDNA gene tree indicated that these strains are indigenous from the Southwest Sumba District.

\section{ACKNOWLEDGMENTS}

This research was supported by The Directorate General of Higher Education, Department of National Education (Hibah Bersaing) 2012, contract no: $560.7 / \mathrm{K} 5 / \mathrm{KL} / 2012$ date $10-02-2012$. A special gratitude is given to Karitas Hospital in Weetabula in Southwest Sumba District and Lende Moripa Hospital in Waikabubak in West Sumba District East Nusa Tenggara for their assistance in collecting the samples. I should also thank Sr. Sili Bouka ADM-the Director of Karitas Hospital, dr. Loeta Lapoe Moekoe-the Director of Lende Moripa Hospital and all doctors of Karitas Hospital for their assistance during the research.

\section{REFERENCES}

Amarantini C, Sembiring L, Kushadiwijaya H, Asmara W. 2009. Seleksi bakteri Salmonella Typhi dari kultur darah penderita demam tifoid [Selection of Samonella Typhi bacteria from the blood culture of typhoid patients]. In: Wijaya A, Darmawan D, Tuti R, Atmanto T, Nurohman S, editors. Revitalisasi MIPA dan Pendidikan MIPA dalam Rangka Penguatan Kapasitas Kelembagaan dan Profesionalisme Menuju World Class University. Proceeding of National Seminar on Research, Education, and Applied of Mathematics and Natural Sciences; 2009 May 16. Yogyakarta(ID): p B13-B20.

Amarantini C, Sembiring L, Kushadiwijaya H, Asmara W. 2009. Isolasi, karakterisasi dan pengelompokan strain Salmonella Typhi asal kabupaten sumba barat daya nusa tenggara timur berdasarkan sifat-sifat fenotip [Isolation, characterization and grouping of Salmonella Typhi strains in the Southwest Sumba Regency East Nusa Tenggara based on phenotypic characteristics. Berkala Penelitian Hayati 14(2):191-196.

Baumler AJ, Tsolis RM, Ficht TA, Adams LG. 1998. Evolution of host adaptation in Salmonella enterica. Infect Immun. 66(10):4579-4587.

Christensen H, Nordentoft S, Olsen JE. 1998. Phylogenetic relationship of Salmonella based on rRNA sequences. Int J Syst Bacteriol. 48(2):605-610. doi:10.1099/0020771348-2-605.

Chun J. 1999. Phylogenetic Editor (PHYDIT). Windows Version.

Drancourt M, Bollet C, Carlioz A, Martelin R, Gayral JP, Raoult D. 2000. 16S Ribosomal DNA sequence analysis of a large collection of environmental and clinical unidentifiable bacterial isolates. J Clin Microbiol. 38(10): 3623-3630.

Felsenstein J. 1993. Phylogeny inference package version 3,5c. Departement of Genetics. Seattle (USA): University of Washington. 
Jukes TH, Cantor CR. 1969. Evolution of protein molecules. In: Munro HN, editors. Mammalian Protein Metabolism. New York: Academic Press. 13:21-132.

Massi MN, Shirakawa T, Gotoh A, Hatta M, Kawabata M. 2005. Identification and sequencing of Salmonella enterica serotype Typhi isolates obtained from patients with perforation and non-perforation typhoid fever. Southeast Asian J Trop Med Publ Health. 36(1):118122.

Moehario LM. 2009. The molecular epidemiology of Salmonella Typhi across Indonesia reveals bacterial migration. J Infect Dev Ctries. 3(8):579-584. doi: $10.3855 /$ jidc.548.

Saitou N, Nei M. 1987. The Neighbor-joining method: a new method for reconstructing phylogenetic trees. Mol Biol Evol. 4(4):406-425.

Shelobolina ES, Sullivan SA, O'Nell KR, Nevin KP, Lovley DR. 2004. Isolation, characterization, and U(VI)-reducing potential of a facultatively anaerobic, acid-resistant bacterium from low-pH, nitrate- and U(VI)-contaminated subsurface sediment and description of Salmonella subterranea sp. nov. Appl Environ Microbiol. 70(5):2959-2965. doi:10.1128/AEM.70.5.29592965.2004.

Tajbakhsh M, Nayer BN, Motavaze K, Kharaziha P, Chiani M, Zali MR, Klena JD. 2011. Phylogenetic relationship of Salmonella enterica strains in Tehran Iran using 16S rRNA and gyrB gene sequences. J Infect Dev Ctries. 5(6): 465-472. doi:10.3855/jidc. 1504.
Thompson JD, Gibson TJ, Plewniak F, Jeanmougin F, Higgins DG. 1997. The CLUSTAL X windows interface: flexible strategies for multiple sequence alignment aided by quality analysis tools. Nucleic Acids Res. 25(24):4876-4882. doi:10.1093/nar/25.24.4876.

Truper HG. 2005. The type species of the genus Salmonella Lignieres 1900 is Salmonella enterica (ex Kauffmann and Edwards 1952) Le Minor and Popoff 1987, with the type strain $\mathrm{LT}^{\mathrm{T}}$, and conservation of the epithet enterica in Salmonella enterica over all earlier epithets that may be applied to this species. Opinion 80. Judicial Commission of the International Committee on Systematics of Prokaryotes. IJSEM. 55(1):519-520. doi:10.1099/ijs.0.63579-0.

WHO 2003. Background Document: The diagnosis, treatment and prevention of typhoid fever. Communicable Disease Surveillance and Response Vaccines and Biologicals. p 1-30; 103-120.

Woo PCY, Leung PKL, Leung KW, Yuen KY. 2000. Identification by $16 \mathrm{~S}$ ribosomal RNA gene sequencing of an Enterobacteriaceae species from a bone marrow transplant recipient. J Clin Pathol. 53(4):211-215. doi:10.1136/mp.53.4.211.

Woo PCY, Fung AMY, Wong SSY, Tsoi HW, Yuen KY. 2001. Isolation and characterization of a Salmonella enterica Serotype Typhi variant and its clinical and public health implications. J Clin Microbiol. 39(3):1190-1194. doi:10.1128/JCM.39.3.1190-1194.2001. 